Testcraft 



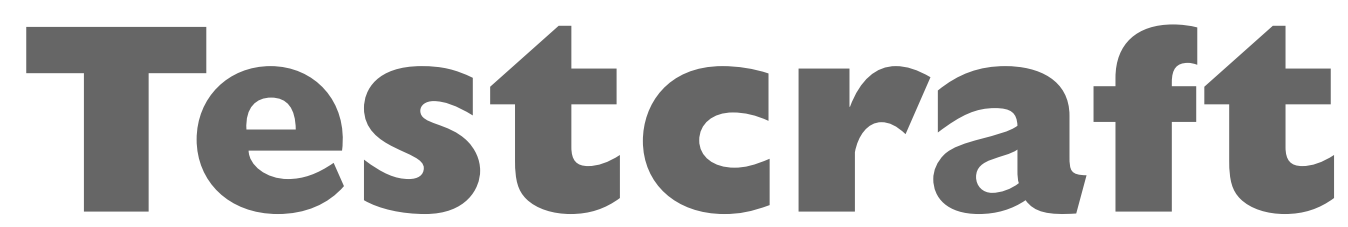

A Teacher's Guide to

Writing and Using

Language Test

Specifications

\section{Fred Davidson}

University of Illinois at

Urbana-Champaign

and

Brian K. Lynch

Portland State University 
Copyright $\odot 2002$ by Yale University.

All rights reserved.

This book may not be reproduced, in whole or in part, including illustrations, in any form (beyond that copying permitted by Sections 107 and 108 of the U.S. Copyright Law and except by reviewers for the public press), without written permission from the publishers.

Publisher: Mary Jane Peluso

Production Controller: Maureen Noonan

Editorial Assistant: Emily Saglimberi

Designer: James J. Johnson

Set in New Aster Roman types by

The Composing Room of Michigan, Inc.

Printed in Canada by VISTAinfo.

\section{Library of Congress Cataloging-in-Publication} Data

Davidson, Fred.

Testcraft : a teacher's guide to writing and using language test specifications / Fred Davidson and Brian K. Lynch.

p. $\mathrm{cm}$.

Includes bibliographical references and index. ISBN 0-300-09006-4 (alk. paper)

1. Language and languages-Ability testing. I. Title: Testcraft. II. Lynch, Brian K. III. Title.

P53.4.D367 2001

$407^{\prime} .6-\mathrm{dc} 21$

2001000800

A catalogue record for this book is available from the British Library.

The paper in this book meets the guidelines for permanence and durability of the Committee on Production Guidelines for Book Longevity of the Council on Library Resources.

1098766543221 
For our students 
